\title{
Abbreviations
}

\section{EMMANUEL LEVINAS}

AS "Au-delà du souvenir," in A l'Heure des Nations (Paris: Les Éditions de Minuit, I988)

B M "Beyond Memory," in In the Time of Nations, trans. Michael B. Smith (New York: Continuum Press, 2007)

C TI "Contempt for the Torah as Idolatry," in In the Time of Nations, trans. Michael B. Smith (New York: Continuum Press, 2007)

M PI "Mépris de la Thora comme idolâtrie," in A l'Heure des Nations (Paris: Les Éditions de Minuit, I988)

ow "As Old as the World," in Nine Talmudic Lessons, trans. Annette Aronowicz (Bloomington: Indiana University Press, 1994)

т т "The Temptation of Temptation," in Nine Talmudic Lessons, trans. Annette Aronowicz (Bloomington: Indiana University Press, 1994)

T TF "La tentation de la tentation," in Quatre Lectures Talmudiques (Paris: Les Éditions de Minuit, I968)

v M "Vieux comme le monde?," in Quatre Lectures Talmudiques (Paris: Les Éditions de Minuit, I968) 
This page intentionally left blank 